Ivana Maletić, M.Sc.

MEP

ivana.maletic@europarl.europa.eu

Vinko Kandžija, Ph.D.

University of Rijeka, Faculty of Economics, Rijeka, Croatia

Libertas International University, Zagreb, Croatia

ECSA BIH, Mostar, Bosnia and Herzegovina

vinko.kandzija@efri.hr

\title{
THE ACCESSION PROCESS AND IPA FUNDS IN BOSNIA AND HERZEGOVINA - AN OPPORTUNITY FOR RESTRUCTURING PUBLIC SPENDING AND CONVERGENCE TOWARDS THE EU
}

\begin{abstract}
The opportunity for submission of B\&H's application for $E U$ membership was opened with the entering into force of the Stabilisation and Association Agreement, and was carried out in February 2016. The membership application must contain European affiliation of the applicant country, inclusion in the European Union as a policy objective of the applicant country, as well as readiness for assuming all objectives and commitments ensuing from membership in the EU. B\&H is at the very bottom compared to Central European countries, and is below 30\% of European Union average in view of level of development. That points to the necessity of implementation of structural reforms in order to mobilize the private sector, which must be the main generator of growth and increase in employment, and which will gradually bring $B \& H$ closer to the EU average. 165,8 billion euros are intended for B\&H from IPA II programme for the period 2014-2017, whereas the amount of available funds for the period 2018-2020 will be defined subsequently. It has been decided that 13,7 million years will be allocated annually for socioeconomic and regional development in 2016 and 2017. In 2014, 4 million euros were allocated for undertakings regarding employment, active social policy, education, research and development, promotion of gender equality and human resources development, and 11 million annually in the following years, including 2017. Reforms financed from IPA
\end{abstract}


should provide citizens with better opportunities and allow for development of standards equal to those of EU citizens.

Keywords: accession proces, $\mathrm{BiH}, \mathrm{EU}, I P A$

\section{JEL: O52}

\section{INTRODUCTION}

The process of accession to the European Union (hereinafter: EU) places numerous challenges before candidate countries, primarily manifested in the need for building democracy and rule of law, observance of human and minority rights, institutional development and building administrative capacities in order for them to be able to successfully participate in European policies. In order for them to be able to achieve the status of a candidate country, they must meet the basic conditions relating to the functioning of democracy, observance of human rights, respect for fundamental rights of all people and rule of law as defined by Article 49 of the basic Treaty on European Union $^{1}$. Every European country can submit an application for EU membership if it respects the common values of Member States and obliges itself to promote them ${ }^{2}$.

Based on the benchmark system which the EU places before candidate countries, an all-encompassing framework allowing for implementation and sustainability of reforms is created in order to achieve high level and quality adjustments, convergence, harmonisation, but also Europeization; candidate countries must fulfil political, legal, economic (defined in Copenhagen in 1993) and administrative criteria (defined in Madrid in 1995). Political criteria demand from candidate countries stability of institutions ensuring rule of law, observance of human rights, protection of minorities, as well as introduction and observance of democratic standards. Fulfilment of

\footnotetext{
${ }^{1}$ Treaty on the Functioning of the European Union, Official Journal of the European Union C 326/13. Available at: http://eur-lex.europa.eu/legalcontent/EN/TXT/PDF/?uri=CELEX:12012M/TXT\&from=en

${ }^{2}$ European Parliament (2013) A short guide to the European Union. Luxembourg: The Publications Office of the European Union
} 
legal criteria demand integration of the EU legal framework in the national system and quality implementation of rules. Within the framework of economic criteria, candidate countries must ensure the existence of a functioning market economy and enable itself for equal participation in the EU single market. Fulfilment of administrative criteria entail ensuring institutional stability and building administrative capacities for fulfilling commitments ensuing from membership in the $\mathrm{EU}^{3}$.

In order to acquire the status of an EU candidate country as well as in addition offulfilling the Questionnaire, Bosnia and Herzegovina (hereinafter: $\mathrm{B} \& \mathrm{H}$ ) needs to solve two important issues. The first one relates to resolving the Sejdić-Finci dispute, that is, amendment of the $\mathrm{B} \& \mathrm{H}$ Constitution in order to allow members of national minorities to be elected to B\&H Presidency and the House of Peoples of the Parliamentary Assembly. The second issue the EU demands to be solved relates to the coordination mechanism. The mechanism concerned would contribute to easier and faster decision-bringing between different government levels in the process of accession to the $\mathrm{EU}$, as well as to quality implementation of adopted laws. It is precisely these two conditions put before B\&H that show how important legal and political criteria are in the process of accession to the EU.

Membership in the EU is extremely important for B\&H because it would open up numerous opportunities for a stronger positioning on the European and international scene and for long-term sustainable and continued growth and development. Opportunities opening with membership in the EU are: access to the single market comprising half a billion consumers, funds from EU funds, favourable financing sources, opportunities for exchange of knowledge, experiences and new technologies, as well as encouraging innovation, research and modernization. However, for a country which is not ready and does not implement the necessary reforms, these opportunities turn into

\footnotetext{
${ }^{3}$ For more detailed information on membership criteria see Negotiations for the Accession of the Republic of Croatia to the (2006) Zagreb: Ministry of Foreign and European Affairs. Available at: http://www.mvep.hr/files/file/publikacije/MEI hr_web_pass.pdf
} 
large obstacles. Precisely for that reason, very demanding criteria are put before the candidate country during negotiations, from which Member States and the Commission do not deviate. With the aim of fulfiling set criteria, the European Union financially supports reforms implemented in the country prior to and during the negotiation process through pre-accession assistance programmes. An overview of the process of B\&H's accession to the EU and changes required in order to achieve stronger and faster convergence are presented hereafter. An overview of main challenges in the context of improving B\&H's competitive position and economic circumstances is also provided. It is apparent from all of this that fulfilment of political and legal criteria directly related to equality of constituent nations and observance of human and minority rights are the basic preconditions for all processes: from convergence towards the EU to economic and social prosperity.

\section{BOSNIA AND HERZEGOVINA'S WAY TO EUROPE}

The process of accession to the European Union (EU) is a long-term process comprised of three phases, each of which is subject to approval by all EU Member States. In the first phase, opportunity for membership is opened to the country ${ }^{4}$. In accordance with the Treaty on European Union, every European country can submit a membership application if it respects the democratic principles of the EU and is dedicated to promoting them. In the second phase the country becomes an official membership candidate, followed by the third phase comprising of formal membership negotiations ${ }^{5}$. During the process of accession to the European Union, every country must take several steps. The first step is the signing of a Stabilisation and Association Agreement, establishing cooperation relations.

\footnotetext{
${ }^{4}$ Strohmeier, R.W., Habets, I. (2013.) EU Policies: an Overview. Brussels: Centre for European Studies

${ }^{5}$ European Neighbourhood Policy And Enlargement Negotiations: Steps towards joining. Available at: https://ec.europa.eu/neighbourhood-enlargement/policy/stepstowards-joining en
} 


\subsection{Stabilisation and Association Agreement}

The first phase in the process of $\mathrm{B} \& \mathrm{H}$ 's accession to the $\mathrm{EU}$ commenced with negotiations on the Stabilisation and Association Agreement in 2005, following which the European Commission estimated that B\&H had made satisfactory progress in implementation of reforms defined in the Feasibility Study for a Stabilisation and Association Agreement (SSP) ${ }^{6}$. A feasibility study is a document in which the capability of countries for realization of contractual relations with the $\mathrm{EU}$ in the stabilisation and association process is analysed and established. Negotiations were closed in 2006, however the Agreement between the $\mathrm{EU}$ and $\mathrm{B} \& \mathrm{H}$ was signed together with the Interim Agreement on Trade and Trade-related Matters (hereinafter: Interim Agreement) as late as in 2008, when the Interim Agreement also entered into force.

In addition to implementation of reforms, amendment of the Constitution in accordance with the Sejdic - Finci $^{7}$ verdict was one of the conditions for the Stabilisation and Association Agreement to enter into force. Political leaders in B\&H did not reach a definitive agreement on the implementation of the Sejdić-Finci verdict, as well as on the establishment of a coordination mechanism for $\mathrm{EU}$ issues. Yet, in December 2014, following a visit by High Representative of the Union for Foreign Affairs and Security Policy Federica Mogherini and Commissioner for European Neigbourhood Policy and Enlargement Negotiations Johannes Hahn, it was decided that a new approach be applied to $\mathrm{B} \& \mathrm{H}$, including complete fulfilment of all criteria and a written confirmation of $\mathrm{B} \& \mathrm{Hs}$ commitment to the way to Europe. Thereby on 1 June 2015 the B\&H Presidency and both houses of the B\&H Parliamentary Assembly confirmed and adopted the Joint Statement on the commitment to undertake the necessary

\footnotetext{
${ }^{6}$ Centre for European Studies: Stabilisation and Association Agreement between the European Communities and their Member States, of the one part, and Bosnia and Herzegovina, of the other part. Available at: http://www.dei.gov.ba/bih_i eu/ssp/doc/default.aspx?id=743\&langTag=bs-BA ${ }^{7}$ European Court of Human Rights: Sejdić and Finci v. Bosnia and Herzegovina (Applications No. 27996/06 and 34836/06). More information available at: http://www.mhrr.gov.ba/ured_zastupnika/novosti/default.aspx?id=1008\&langTag=b $\underline{\mathrm{s}-\mathrm{BA}}$
} 
reforms in the EU accession process, in accordance with the Conclusions of the EU Foreign Affairs Council. On the same day, 1 June 2015, the EU allowed for the B\&H Stabilisation and Association Agreement to enter into force.

\subsection{Submission of EU membership application}

The opportunity for submission of B\&H's application for EU membership was opened with the entering into force of the Stabilisation and Association Agreement, and was carried out in February 2016. The membership application must contain European affiliation of the applicant country, inclusion in the European Union as a policy objective of the applicant country, as well as readiness for assuming all objectives and commitments ensuing from membership in the $\mathrm{EU}^{8}$.

Following the reception of the application for membership, the Council calls on the European Commission to draw up an opinion on the application for membership (avis). During that process the European Commission sends to the applicant country a questionnaire consisting of a general part (common for all countries) and a special part (questions regarding the country which the questionnaire relates to). The European Commission's questionnaire which the government of $\mathrm{B} \& \mathrm{H}$ had to respond to within a three-month deadline was delivered on 9 December 2016. An overview of key developments in relations between $\mathrm{B} \& \mathrm{H}$ and the $\mathrm{EU}$ is provided in Table 1 hereafter.

After B\&H delivers its answers to the Questionnaire, the European Commission will bring an opinion (avis) on its preparedness for acceptance and fulfilment of conditions for membership, which can be positive or negative. Based on European Commission's opinion, the European Council approves the status of a candidate country to the applicant country.

\footnotetext{
${ }^{8}$ Initiative for Monitoring BiH's EU Integration Process: Steps Towards EU Membership. More information available at: http://eu-monitoring.ba/koraci-kaclanstvu-evropskoj-uniji/
} 
Table 1: Key developments in relations between B\&H and the EU

\begin{tabular}{|c|c|}
\hline Date & Development \\
\hline 1997 & $\begin{array}{l}\text { Council of the European Union sets the political and economic } \\
\text { conditions for development of bilateral relations. Bosnia and } \\
\text { Herzegovina is provided with the opportunity of using autonomous } \\
\text { trade measures. }\end{array}$ \\
\hline 1998. & $\begin{array}{l}\text { Setting up of the EU - B\&H Consultative Task Force - CTF, which } \\
\text { ensures technical and expert assistance in the areas of administration, } \\
\text { legal framework and policy. }\end{array}$ \\
\hline May 1999 & $\begin{array}{l}\text { Commencement of the Stabilisation and Association Process - SAP. } \\
\text { The Stabilisation and Association Process offers a clear opportunity for } \\
\text { EU integration to Bosnia and Herzegovina, as well as the other five } \\
\text { countries in the Western Balkans Region. }\end{array}$ \\
\hline June 1999 & $\begin{array}{l}\text { Commencement of activities of the Stability Pact for South-Eastern } \\
\text { Europe, whose strategic objective is stabilization in South-Eastern } \\
\text { Europe through approaching countries in the region to Euro-Atlantic } \\
\text { Integration, as well as strengthening regional cooperation. In June } 1999 \\
\text { in Sarajevo a summit of heads of countries and governments from } \\
\text { Europe, Canada, Japan and USA took place, at which the establishment } \\
\text { of a Stability Pact for South-Eastern Europe was upheld. }\end{array}$ \\
\hline $\begin{array}{l}\text { March } \\
2000\end{array}$ & $\begin{array}{l}\text { Publication of the EU Road Map. This document defined } 18 \text { key } \\
\text { conditions which Bosnia and Herzegovina must fulfil in order for the } \\
\text { drawing up of a Feasibility Study for opening negotiations on the } \\
\text { Stability and Association Agreement (SAA) to commence. }\end{array}$ \\
\hline 2000 & $\begin{array}{l}\text { Introduction of a duty-free access of products from Bosnia and } \\
\text { Herzegovina to the internal market of the European Union (Autonomus } \\
\text { Trade Measure - ATM). }\end{array}$ \\
\hline \begin{tabular}{|l|} 
December \\
2000
\end{tabular} & $\begin{array}{l}\text { Council of the European Union adopts Regulation } 2666 / 2000 \text { on } \\
\text { Community Assistance for Reconstruction, Development and } \\
\text { Stabilisation - CARDS programme . CARDS was a European Union } \\
\text { programme for reconstruction, development and stabilisation intended } \\
\text { for Albania, Bosnia and Herzegovina, Croatia, Macedonia and Federal } \\
\text { Republic of Yugoslavia (Serbia and Montenegro). }\end{array}$ \\
\hline \begin{tabular}{|l|} 
March \\
2003
\end{tabular} & $\begin{array}{l}\text { Commencement of work on the Feasibility Study. The European } \\
\text { Commission delivered to the Council of Ministers of } \mathrm{B} \& \mathrm{H} \text { a } \\
\text { questionnaire with } 346 \text { questions covering the area of economic and } \\
\text { political organization of B\&H, which were relevant for the conclusion } \\
\text { of the Stabilisation and Association Agreement. }\end{array}$ \\
\hline \begin{tabular}{|l|} 
November \\
2003
\end{tabular} & $\begin{array}{l}\text { The European Commission adopts the evaluation of the Feasibility } \\
\text { Study. The Feasibility Study identified } 16 \text { priority areas basic reform } \\
\text { progress in which would serve as a basis for the European Commission } \\
\text { to recommend opening negotiations on the Stabilisation and } \\
\text { Association Agreement with B\&H to the European Council. }\end{array}$ \\
\hline \begin{tabular}{|l|l|l} 
March \\
2004
\end{tabular} & $\begin{array}{l}\text { European Council adopts the first European Partnership with Bosnia } \\
\text { and Herzegovina }\end{array}$ \\
\hline $\begin{array}{l}\text { November } \\
2005\end{array}$ & $\begin{array}{l}\text { On } 25 \text { November negotiations on the Stabilisation and Association } \\
\text { Agreement officially opened in Sarajevo. }\end{array}$ \\
\hline
\end{tabular}




\begin{tabular}{|c|c|}
\hline $\begin{array}{l}\text { January } \\
2006\end{array}$ & $\begin{array}{l}\text { The First Plenary Round on Negotiations on the SAA between the EU } \\
\text { and B\&H and the First Plenary Meeting of the Reform Process } \\
\text { Monitoring - RPM, which replaced the former Advisory Working } \\
\text { Body, held. The European Council adopts the second European } \\
\text { Partnership with Bosnia and Herzegovina. }\end{array}$ \\
\hline $\begin{array}{l}\text { January } \\
2007\end{array}$ & $\begin{array}{l}\text { Instrument for Pre-accession Assistance - IPA, intended for all pre- } \\
\text { accession activities financed by the European Commission established. }\end{array}$ \\
\hline February & European Council adopts the third European Partnership with Bosnia \\
\hline 2008 & and Herzegovina. \\
\hline $\begin{array}{l}\text { November } \\
2007\end{array}$ & $\begin{array}{l}\text { Technical negotiations on the Stabilisation and Association Agreement } \\
\text { closed, signing depending on fulfilment of political conditions. }\end{array}$ \\
\hline $\begin{array}{l}\text { December } \\
2007\end{array}$ & Stabilisation and Association Agreement concluded on 4 December. \\
\hline $\begin{array}{l}\text { February } \\
2008\end{array}$ & $\begin{array}{l}\text { Framework agreement between } \mathrm{BiH} \text { and Commission of the European } \\
\text { Communities on the rules for cooperation to implement EC financial } \\
\text { assistance to } \mathrm{BiH} \text { under the Instrument for Pre-Accession Assistance } \\
\text { (IPA) signed on } 20 \text { February. }\end{array}$ \\
\hline June 2008 & Stabilisation and Association Agreement signed on 16 June. \\
\hline July 2008 & $\begin{array}{l}\text { Interim Agreement on Trade and Trade-related Matters enters into } \\
\text { force on } 1 \text { July. }\end{array}$ \\
\hline $\begin{array}{l}\text { November } \\
2008\end{array}$ & $\begin{array}{l}\text { The first meeting of the Interim Stabilisation and Association } \\
\text { Committee, as the highest body within the framework of the } \\
\text { stabilisation and association process, whose basic task (together with } \\
\text { six interim sub-committees) was to monitor the fulfilment of } \\
\text { obligations from the Interim Agreement, held. }\end{array}$ \\
\hline June 2011. & $\begin{array}{l}\text { The first meeting of the Structured Dialogue on Justice between Bosnia } \\
\text { and Herzegovina and the European Union held. }\end{array}$ \\
\hline $\begin{array}{l}27 \text { June } \\
2012\end{array}$ & $\begin{array}{l}\text { The first meeting of the High Level Dialogue on the Accession Process } \\
\text { with Bosnia and Hercegovina held when the Road Map for BiH's EU } \\
\text { membership application was delivered. The second meeting was held } \\
\text { in November } 2012 \text {. }\end{array}$ \\
\hline $\begin{array}{l}01 \text { July } \\
2013\end{array}$ & $\begin{array}{l}\text { The Republic of Croatia becomes the } 28 \text { th EU Member State, and } \\
\text { Bosnia and Herzegovina borders with a European Union Member State } \\
\text { for the first time }\end{array}$ \\
\hline $\begin{array}{l}\text { January } \\
2014\end{array}$ & $\begin{array}{l}\text { The EU establishes the new Instrument for Pre-accession Assistance } \\
\text { IPA II, for the period } 2014-2020 \text {. }\end{array}$ \\
\hline $\begin{array}{l}\text { 01 June } \\
2015\end{array}$ & $\begin{array}{l}\text { Stabilisation and Association Agreement between the EU and Bosnia } \\
\text { and Herzegovina enters into force }\end{array}$ \\
\hline $\begin{array}{l}15 \\
\text { February } \\
2016\end{array}$ & $\begin{array}{l}\text { In accordance with Article } 49 \text { of the Treaty on European Union, within } \\
\text { the framework of the Netherlands EU presidency, B\&H submits a } \\
\text { formal „EU membership application“. }\end{array}$ \\
\hline $\begin{array}{l}20 \\
\text { September } \\
2016\end{array}$ & $\begin{array}{l}\text { The European Council calls on the European Commission to prepare } \\
\text { an opinion on B\&H's Application for EU membership }\end{array}$ \\
\hline $\begin{array}{l}09 \\
\text { December } \\
2016\end{array}$ & The European Commission receives the Questionnaire \\
\hline
\end{tabular}

Source: Directorate for European Integration: Chronology of relations between B\&H and the EU. Available at:

http://www.dei.gov.ba/dei/bih_eu/default.aspx?id=9808\&langTag=hr-HR 


\subsection{Negotiations on the acceptance and application of $\mathbf{E} \mathbf{U}$ acquis communautaire}

After obtaining the status of a candidate country follows the opening of negotiations on chapters of the EU acquis, consisting of an analytical review and an evaluation of conformity of national legislation with the EU acquis (screening), as well as the substantive negotiations phase, during which conditions for acceptance and application of the EU acquis are negotiated, including transitional periods and exemptions ${ }^{9}$.

Negotiations are closed after all benchmarks have been fulfilled and all negotiation chapters closed. After the closure of negotiations follows the signing of the Treaty of Accession, which also comprises all results of the negotiations. The Treaty of Accession must be ratified by the European Parliament, parliaments of all Member States and the parliament of the acceding country. Full membership in the EU is attained with entry into force of the Treaty of Accession, that is, on the set date of accession.

In order to become an EU Member State, B\&H must fulfil criteria (opening and closing benchmarks) from 35 chapters ${ }^{10}$. In addition to adopting the EU legal system through fulfilment of benchmarks from the chapters, B\&H will implement numerous reforms in order to prepare for equal (compared to other Member States), active and successful participation in all common EU policies and in the European single market. Chapters to be opened first and closed last are Chapter 23 - Judiciary and fundamental rights and Chapter 24 Justice, freedom and security. Through Chapter 23 strengthening of independence, impartiality and professionalism in the judiciary,

\footnotetext{
${ }^{9}$ European Neighbourhood Policy and Enlargement Negotiations: Screening of the acquis. Available at: https://ec.europa.eu/neighbourhoodenlargement/policy/glossary/terms/screening en

${ }^{10}$ Ministry of Foreign and European Affairs: Summary of results of accession negotiations as per chapters. Available at:

http://www.mvep.hr/custompages/static/hrv/files/pregovori/120112-sazeti.pdf
} 
implementation of prevention measures, fight against corruption and preservation of high standards of human and minority rights protection in $\mathrm{B} \& \mathrm{H}$ are requested. Chapter 24 regulates state border management, visa and asylum policies, legal migration, suppression of illegal migration, organized crime, drug trafficking trade, terrorism, judicial cooperation in criminal and civil matters and cooperation between tax, customs and judicial authorities in order to enhance the freedoms and improve the security of citizens. Efficient control of EU outer land and maritime borders will additionally impede endangering of security from outside the EU. Through joint activities in the fight against organized crime, goods and human trafficking and drug trade, citizens of B\&H will enjoy a higher degree of security.

Negotiations as per chapters and reforms which must be implemented during negotiations help the country to professionalize the administration, establish control and prevention systems as well as mechanisms to regulate business processes and procedures, improve the quality of management and work, regulate the market, improve public policies such as the healthcare system, education, science, culture, energy, foreign policy, introduce the rule of law and improve democratic standards etc. Precisely for these reasons the accession process is extremely important for $\mathrm{B} \& \mathrm{H}$, which needs to introduce the partnership principle and clearly define the competences and responsibilities of each level of government. Equality of all three constituent nations, manifesting among other things in equal participation in all institutions and decision-making processes, is of the key importance for development of $\mathrm{B} \& \mathrm{H}$ based on European values.

\section{PRE-ACCESSION ASSISTANCE PROGRAMMES IN B\&H - SUPPORT TO CHANGES ON THE WAY TO THE EU}

The budget of IPA programme for the period 2007-2013 amounted to 11,5 billion euros for all candidate and potential candidate countries, whereas the budget of IPA II programme for the period 2014-2020 amounts to 11,7 billion euros. The Framework Agreement represents 
the basis for using IPA II (2014-2020) programme funds, and is concluded between the European Commission and IPA II programme beneficiary countries. The Agreement defines the principles of financial cooperation between beneficiary countries and the Commission ${ }^{11}$. The IPA II Framework Agreement between Bosnia and Herzegovina and the European Commission entered into force on 24 August $2015^{12}$. In addition to Bosnia and Herzegovina, the current beneficiaries of IPA II programme are Albania, Macedonia, Kosovo, Turkey, Serbia and Montenegro. The basic intention of IPA programme is to support beneficiary countries in the implementation of political and economic reforms, preparing them for the rights and obligations ensuing from membership in the EU. IPA II programme aims at reforms within the framework of defined sectors. Those sectors cover areas closely related to the enlargement strategy, such as:

- Democracy and governance - implying institutional strengthening, reform and improvement of economic governance, fight against corruption, better public finance management,

- Rule of law - implying improvement of judicial institutions and the principles of legal responsibility, efficiency, independence and impartiality. It also also implies fight against organized crime, solving deficiencies in the protection of fundamental human rights and fight against corruption,

- Growth, competitiveness and innovation - implying better implementation of reforms in the area of economic governance in order to achieve a high level of competitiveness and development of human capital,

- Employment, education and better social policy - implying implementation of reforms regarding labour market institutions in order to set wages, establish syndicates and ensure better working conditions in a better and more just way.

\footnotetext{
${ }^{11}$ Defined under the framework of Commission's Implementing regulation No. 447/2014 of 2. May 2014. on the specific rules for implementing Regulation (EU) No 231/2014 of the European Parliament and of the Council establishing an Instrument for Pre-accession assistance (IPA II), Official Journal of the European Union, L 132, 03.05.2014., page 32-52

$12 \mathrm{http://www.dei.gov.ba/dei/direkcija/sektor} \mathrm{koordinacija/ipa} \mathrm{2/default.aspx?id=11610}$

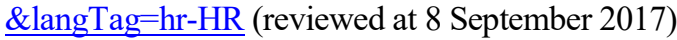


A table overview of financial assistance for B\&H from IPA II programme is presented hereafter.

Table 1. Indicative allocation of funds to Bosnia and Herzegovina (excluding allocation of funds for cross-border cooperation), in millions of euros

\begin{tabular}{|c|c|c|c|c|c|}
\hline Areas/years & 2014 & 2015 & 2016 & 2017 & $\begin{array}{l}\text { Total } \\
\text { for the } \\
\text { period } \\
2014- \\
2017\end{array}$ \\
\hline $\begin{array}{l}\text { Reforms in preparation for } \mathrm{EU} \\
\text { memberhip }\end{array}$ & 11 & 17 & 18 & 18 & 64 \\
\hline Democracy and governance & \multicolumn{4}{|c|}{31} & 31 \\
\hline Rule of law & \multicolumn{4}{|c|}{33} & 33 \\
\hline $\begin{array}{l}\text { Socioeconomic and regional } \\
\text { development }\end{array}$ & 24,7 & 11,7 & 13,7 & 13,7 & 63,8 \\
\hline $\begin{array}{l}\text { Competitiveness and innovation: } \\
\text { local development strategies }\end{array}$ & \multicolumn{4}{|c|}{63,8} & 63,8 \\
\hline $\begin{array}{l}\text { Employment, social policies, } \\
\text { education, research and } \\
\text { development, promotion of } \\
\text { gender equality, human } \\
\text { resources development }\end{array}$ & 4 & 11 & 11 & 11 & 38 \\
\hline $\begin{array}{l}\text { Education, employment, social } \\
\text { policies }\end{array}$ & \multicolumn{4}{|c|}{38} & 38 \\
\hline Total & 39,7 & 39,7 & 42,7 & 43,7 & 165,8 \\
\hline
\end{tabular}

Source: Author according to data available on European Commission website (2017), “Bosnia and Herzegovina - financial assistance”, available at:

https://ec.europa.eu/neighbourhood-enlargement/instruments/funding-bycountry/bosnia-herzegovina en, reviewed on 8 September 2017.

165,8 billion euros are intended for B\&H from IPA II programme for the period 2014-2017, whereas the amount of availabe funds for the period 2018-2020 will be defined subsequently ${ }^{13}$. Allocation of funds for reforms in the preparation for EU membership has grown from 11 million in the initial year to 18 million euros in the last year observed. In the area of socioeconomic and regional development, 24,7 million

\footnotetext{
${ }^{13}$ https://ec.europa.eu/neighbourhood-enlargement/instruments/funding-bycountry/bosnia-herzegovina en (reviewed at 8 September 2017)
} 
euros were allocated in 2014, however in time the amount decreased to 11 million euros in 2015 . It has been decided that 13,7 million years will be allocated annually for socioeconomic and regional development in 2016 and 2017. In 2014, 4 million euros were allocated for undertakings regarding employment, active social policy, education, research and development, promotion of gender equality and human resources development, and 11 milion annually in the following years, including 2017. Reforms financed from IPA should provide citizens with better opportunities and allow for deveopment of standards equal to those of EU citizens.

The most important novelty with regard to IPA II programme is its strategic focus. Strategic documents for beneficiary countries are specific planning documents drawn up for each beneficiary country for a 7-year period. IPA programme consists of five poicy areas within the framework of which different interventions will be carried out: 1 . The process of transition towards membership and capacity building, 2. Regional development, 3. Employment, social policies and human resources development, 4. Agriculture and rural development, 5. Regional and territorial cooperation.

$\mathrm{B} \& \mathrm{H}$ has not yet established the structure required for independent management of IPA funds under control of the EU Delegation. The EU Delegation in $\mathrm{B} \& \mathrm{H}$ is responsible for implementation of financial support, meaning that it contracts and implements all projects in $\mathrm{B} \& \mathrm{H}$ financed from IPA funds, in addition to ensuring coordination of support with Member States.

Establishment of a coordination mechanism for issues relating to the EU and sectoral strategies for the entire country remain the key conditions for realising full benefit of financing from IPA programme. It is necessary to make progress in the establishment of required institutional structures which would allow for the use of the Instrument for Pre-Accession Assistance in Rural Development (IPARD). B\&H has not yet drawn up a strategic rural development plan at state level. A revised agriculture, food and rural development harmonisation programme, as well as laws on the production of wine and organic food at state level, are yet to be adopted, Administrative capacities and coordination structures in the agriculture and rural 
development sector, including support measures, require further strengthening. B\&H participates in the following EU programmes: Horizon 2020, Creative Europe (which merges former Culture and MEDIA programmes), Fiscalis 2020, Customs 2020, Europe for Citizens and COSME programme.

\section{COMPARISON OF BOSNIA AND HERZEGOVINA WITH OTHER COUNTRIES BASED ON INTERNATIONAL COMPETITIVENESS ANALYSES}

Through analysis of B\&H's competitiveness and its comparison with other countries in the world, a quality basis for continued monitoring of competitiveness in terms of quality of factors on which the attractiveness of the area for business start-up and living depends is gained. Competitiveness analyses provide a clear overview of key weaknesses and advantages of each country and recommendations for strengthening the competitiveness of the economy at the national level. Fast changes are lacking in $\mathrm{B} \& \mathrm{H}$, and therefore so is visible progress in competitiveness and attractiveness to investors. National competitiveness could be increased through the use of territorial advantages and resources, elimination of obstacles to growth and encouraging potential sources.

With the aim of increasing national competitiveness, it is necessary to focus on implementation of structural reforms, especially in those segments in which B\&H is lowest evaluated according to international competitiveness analyses, such as labour market efficiency, regulatory burden, public trust in politicians, efficiency of legal framework, intensity of local competitiveness, ability of the country to attract and retain motivated individuals, high unemploymnet rate, low cluster development level, low innovation capacity and many others.

Table 2 shows that in a ten-year period $\mathrm{B} \& \mathrm{H}$ has dropped by 18 positions according to the Global Competitiveness Report and by 23 positions according to the Social Development Report. Its position improved according to the Doing Business Report, however only by 6 positions, and $\mathrm{B} \& \mathrm{H}$ is still ranked lowest compared to other surrounding countries observed. It is clearly visible that compared to 
observed countriesthe difference has increased and that $\mathrm{B} \& \mathrm{H}$ has fallen behind in the ten-year period, and newer Central and Eastern European Member States, as well as surrounding non membercountries were included in the analysis.

Table 2: Position of $\mathrm{B} \& \mathrm{H}$ in international competitiveness rankings

\begin{tabular}{|c|c|c|c|c|c|c|c|c|c|c|c|c|}
\hline \multirow{2}{*}{ Country } & \multicolumn{3}{|c|}{$\begin{array}{c}\text { Global } \\
\text { Competitiveness } \\
\text { Report }\end{array}$} & \multicolumn{3}{|c|}{$\begin{array}{l}\text { Doing Business } \\
\text { Report }\end{array}$} & \multicolumn{3}{|c|}{$\begin{array}{l}\text { Global Information } \\
\text { Technology Report }\end{array}$} & \multicolumn{3}{|c|}{$\begin{array}{c}\text { Social Development } \\
\text { Report }\end{array}$} \\
\hline & 2006 & 2016 & $\begin{array}{c}\text { Chang } \\
\text { e }\end{array}$ & 2006 & 2017 & $\begin{array}{c}\text { Chang } \\
\text { e }\end{array}$ & 2005 & 2016 & $\begin{array}{c}\text { Chang } \\
\text { e }\end{array}$ & 2006 & 2015 & $\begin{array}{c}\text { Chang } \\
\text { e }\end{array}$ \\
\hline $\begin{array}{c}\text { Czech } \\
\text { Republic }\end{array}$ & 29 & 31 & -2 & 41 & 27 & 14 & 33 & 36 & -3 & 30 & 28 & 2 \\
\hline Poland & 48 & 36 & 12 & 54 & 24 & 30 & 47 & 42 & 5 & 37 & 36 & 1 \\
\hline Hungary & 41 & 69 & -28 & 52 & 41 & 11 & 36 & 50 & -14 & 35 & 44 & -9 \\
\hline Romania & 68 & 62 & 6 & 78 & 36 & 42 & 61 & 66 & -5 & 60 & 52 & 8 \\
\hline Slovenia & 33 & 56 & -23 & 63 & 30 & 33 & 30 & 37 & -7 & 27 & 25 & 2 \\
\hline Croatia & 51 & 74 & -23 & 118 & 43 & 75 & 48 & 54 & -6 & 44 & 47 & -3 \\
\hline Estonia & 25 & 30 & -5 & 16 & 12 & 4 & 25 & 22 & 3 & 40 & 30 & 10 \\
\hline Lithuania & 40 & 35 & 5 & 15 & 21 & -6 & 42 & 29 & 13 & 41 & 37 & 4 \\
\hline Slovakia & 37 & 65 & -28 & 37 & 33 & 4 & 41 & 47 & -6 & 42 & 35 & 7 \\
\hline Bulgaria & 72 & 50 & 22 & 62 & 39 & 23 & 67 & 69 & -2 & 54 & 59 & -5 \\
\hline $\begin{array}{c}\text { Macedoni } \\
\text { a } \\
\end{array}$ & 80 & 68 & 12 & 81 & 10 & 71 & 75 & 46 & 29 & 66 & 81 & -15 \\
\hline Latvia & 36 & 49 & -13 & 26 & 14 & 12 & 35 & 32 & 3 & 45 & 46 & -1 \\
\hline $\begin{array}{c}\text { Monteneg } \\
\text { ro }\end{array}$ & 87 & 82 & 5 & 92 & 51 & 41 & 77 & 51 & 26 & I & 49 & / \\
\hline Serbia & 87 & 90 & -3 & 92 & 47 & 45 & 77 & 75 & 2 & 1 & 66 & 1 \\
\hline $\begin{array}{c}\text { Bosnia } \\
\text { and } \\
\text { Herzegov } \\
\text { ina }\end{array}$ & 89 & 107 & -18 & 87 & 81 & 6 & I & 97 & I & 62 & 85 & -23 \\
\hline Albania & 98 & 80 & 18 & 117 & 58 & 59 & I & 84 & 1 & 73 & 85 & -12 \\
\hline
\end{tabular}

Source: Global Competitveness Report ${ }^{14}$, Doing Business Report ${ }^{15}$, Global Information Technology Report ${ }^{16}$, Social Development Report ${ }^{17}$

${ }^{14}$ World Economic Forum: Global Competitiveness Report. Available at: http://www3.weforum.org/docs/GCR2016-

2017/05FullReport/TheGlobalCompetitivenessReport2016-2017 FINAL.pdf

${ }^{15}$ World Bank: Doing Business Report. Available at:

http://www.doingbusiness.org/ /media/WBG/DoingBusiness/Documents/Annual-

Reports/English/DB17-Report.pdf

${ }^{16}$ World Economic Forum: Global Information Technoogy Report. Available at:

http://www3.weforum.org/docs/GITR2016/WEF_GITR_Full_Report.pdf

${ }^{17}$ United Nations Development Programme: Social Development Report. Available at: http://hdr.undp.org/sites/default/files/2015 human_development_report.pdf 
Competitiveness analyses of $\mathrm{B} \& \mathrm{H}$ show that political stability, legal security and predictability, fight against corruption and fraud,observance of human rights and freedoms are extremely important for strengthening entrepreneurship. It was expected that a favourable business environment, fast and efficient public administration, availability of financing and a regulated market would be the most important factor for competitiveness, however analyses presented hereafter show that political and legal criteria are prominent as more important than economic criteria alone.

\subsection{Global Competitiveness Report}

The Global Competitveness Report measures the competitiveness of 138 countries in different phases of economic development. The methodology of the World Economic Forum is based on an analysis of 12 competitiveness factors, including insititutions, infrastructure, macroeconomic environment, healthcare system, primary education, higher education, labour market efficiency, goods market efficiency, technological readiness, financial market, market size, business sophistication and innovation. Each competitiveness factor is analysed in more detail according to a series of indicators.

Table 3 shows individual evaluation for each area of competitiveness over a period of ten years. Due to unreliable data and assessments, Bosnia and Herzegovina was excluded from the Report for 2014. Although results from 2016 record improvement in several areas (institutions, macroeconomic environment, higher education, labour and goods market efficiency, technological readiness and business sophistication) compared to results from the preceding year, analysis of results from 2016 and their comparison with results from recent years show deterioration or stagnation in most areas. During that period, B\&H was ranked above the 100th position in most categories, which makes it lowest-ranked in relation to surrounding countries. In order to achieve a visible advancement, intensive reforms are required in all areas, especially relating to strengthening institutions, infrastructure, goods and labour market efficiency, business sophistication and innovation. With regard to increasing the inovativeness level, the Global Competitiveness Report recommends more intensive use of ICT because widespread use of information- 
communication technology contributes to new business models and progress of industries, thereby affecting increase in innovativeness, and consequently increase in competitiveness in the long term.

Table 3. Position of B\&H in the Global Competitiveness Report in the period from 2010 to 2016 according to a series of indicators

\begin{tabular}{|c|c|c|c|c|c|c|c|c|c|c|c|c|}
\hline & 旡 & 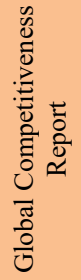 & 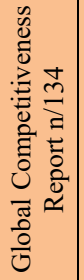 & 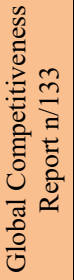 & 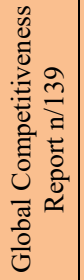 & 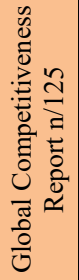 & 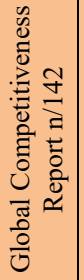 & 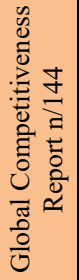 & 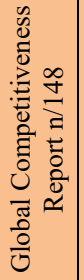 & 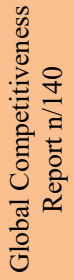 & 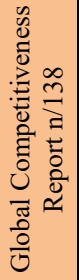 & 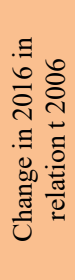 \\
\hline & & 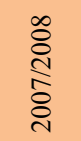 & 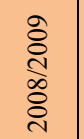 & 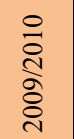 & $\begin{array}{l}\text { 三 } \\
\stackrel{\text { c }}{o} \\
\text { o }\end{array}$ & 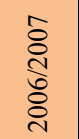 & 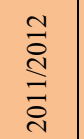 & 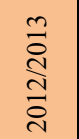 & 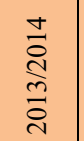 & $\begin{array}{l}\frac{n}{0} \\
\text { ì } \\
\text { d } \\
\text { ָे }\end{array}$ & 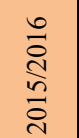 & 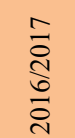 \\
\hline 1 & Institutions & 89 & $\mathrm{n} / \mathrm{a}$ & 123 & 128 & 126 & 109 & 85 & 71 & / & 127 & 126 \\
\hline 2 & Infrastructure & 96 & $\mathrm{n} / \mathrm{a}$ & 123 & 128 & 98 & 99 & 94 & 83 & 1 & 103 & 105 \\
\hline 3 & $\begin{array}{c}\text { Macroeconomic } \\
\text { environment }\end{array}$ & 45 & $\mathrm{n} / \mathrm{a}$ & 57 & 69 & 81 & 78 & 97 & 104 & / & 98 & 76 \\
\hline 4 & $\begin{array}{c}\text { Healthcare } \\
\text { system and } \\
\text { primary } \\
\text { education }\end{array}$ & 38 & $\mathrm{n} / \mathrm{a}$ & 82 & 75 & 89 & 58 & 48 & 46 & / & 48 & 50 \\
\hline 5 & $\begin{array}{c}\text { Higher } \\
\text { education } \\
\text { system and } \\
\text { training }\end{array}$ & 86 & $\mathrm{n} / \mathrm{a}$ & 109 & 86 & 88 & 86 & 72 & 63 & / & 97 & 92 \\
\hline 6 & $\begin{array}{c}\text { Goods market } \\
\text { efficiency }\end{array}$ & 93 & $\mathrm{n} / \mathrm{a}$ & 123 & 125 & 127 & 115 & 109 & 104 & / & 129 & 129 \\
\hline 7 & \begin{tabular}{|c|}
$\begin{array}{c}\text { Labour market } \\
\text { efficiency }\end{array}$ \\
\end{tabular} & $\mathrm{n} / \mathrm{a}$ & $\mathrm{n} / \mathrm{a}$ & 85 & 94 & 94 & 85 & 99 & 88 & I & 131 & 125 \\
\hline 8 & $\begin{array}{c}\text { Financial } \\
\text { market } \\
\text { development } \\
\text { level }\end{array}$ & $\mathrm{n} / \mathrm{a}$ & $\mathrm{n} / \mathrm{a}$ & 86 & 104 & 113 & 124 & 119 & 113 & I & 113 & 101 \\
\hline 9 & $\begin{array}{l}\text { Technological } \\
\text { readiness }\end{array}$ & 108 & $\mathrm{n} / \mathrm{a}$ & 109 & 95 & 85 & 73 & 68 & 73 & / & 79 & 76 \\
\hline 10 & Market size & $\mathrm{n} / \mathrm{a}$ & $\mathrm{n} / \mathrm{a}$ & 92 & 90 & 93 & 97 & 93 & 98 & 7 & 97 & 98 \\
\hline 11 & $\begin{array}{c}\text { Business } \\
\text { sophistication }\end{array}$ & 92 & $\mathrm{n} / \mathrm{a}$ & 125 & 117 & 115 & 108 & 109 & 110 & I & 125 & 115 \\
\hline 12 & Innovation & 104 & $\mathrm{n} / \mathrm{a}$ & 128 & 131 & 120 & 104 & 80 & 63 & 7 & 115 & 125 \\
\hline
\end{tabular}

Source: Global Competitiveness Report 2006/2007 $7^{18}$, 2007/2008, 2008/2009 ${ }^{19}$, $2009 / 2010^{20}, 2010 / 2011^{21}, 2011 / 2012^{22}, 2012 / 2013^{23}, 2013 / 2014^{24}, 2014 / 2015^{25}$, $2015 / 2016^{26}, 2016 / 2017^{27}$

${ }^{18}$ http://www3.weforum.org/docs/WEF_GlobalCompetitivenessReport 2006-07.pdf 
The most problematic factors for starting a business in Bosnia and Herzegovina according to perceptual data obtained through an opinion survey carried out among 80 entrepreneurs are presented hereafter.

Figure 1. Entrepreneurial perception of the most problematic factors for doing business in Bosnia and Herzegovina according to the Global Competitiveness Report for 2016-2017.

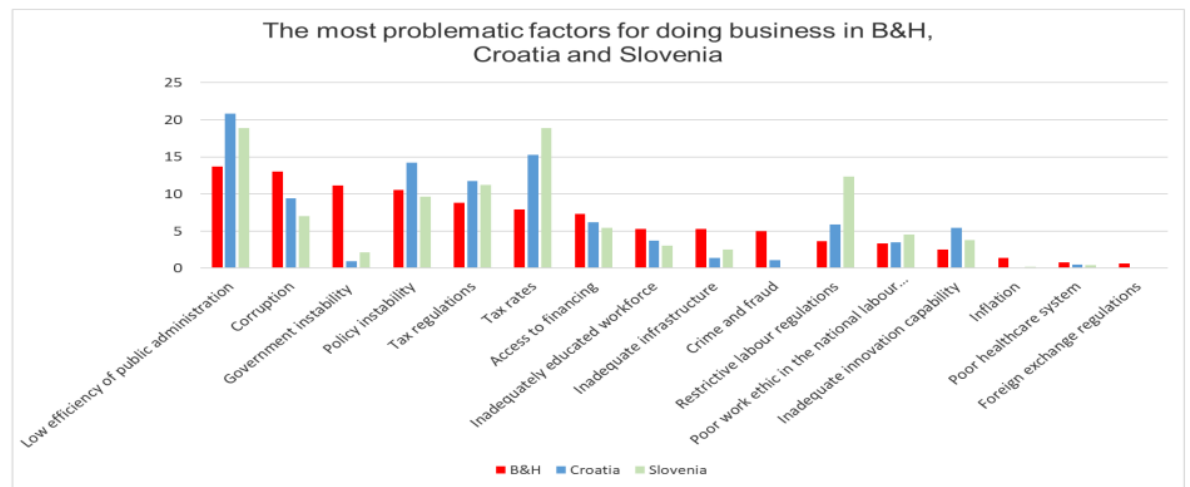

Source: Global Competitiveness Report, Entrepreneurship survey carried out in 2017

In addition to analysing statistical data, the Global Competitiveness Report also provides insight into the most problematic factors for business start-up based on carrying out opinion surveys among entrepreneurs. With regard to the business environment in Bosnia and Herzegovina, the business sector points out low efficiency of public administration, corruption, government instability, policy instability,

${ }^{19} \mathrm{http}$ ://www3.weforum.org/docs/WEF GlobalCompetitivenessReport 2008-09.pdf

${ }^{20} \mathrm{http} / / / \mathrm{www} 3$.weforum.org/docs/WEF_GlobalCompetitivenessReport 2009-10.pdf

${ }^{21} \mathrm{http://www3.weforum.org/docs/WEF} \mathrm{GlobalCompetitivenessReport} \mathrm{2010-11.pdf}$

${ }^{22} \mathrm{http}$ ://www3.weforum.org/docs/WEF_GCR Report 2011-12.pdf

${ }^{23} \mathrm{http}$ ://www3.weforum.org/docs/WEF GlobalCompetitivenessReport 2012-13.pdf

${ }^{24} \mathrm{http}$ ://www3.weforum.org/docs/WEF GlobalCompetitivenessReport 2013-14.pdf

${ }^{25} \mathrm{http} / / / \mathrm{www} 3 . w e f o r u m . o r g / d o c s / W E F$ GlobalCompetitivenessReport 2014-15.pdf

${ }^{26} \mathrm{http}: / / \mathrm{www} 3 . w e f o r u m . o r g /$ docs/gcr/2015-

2016/Global_Competitiveness_Report_2015-2016.pdf

${ }^{27}$ http://www3.weforum.org/docs/GCR2016-

2017/05FullReport/TheGlobalCompetitivenessReport2016-2017_FINAL.pdf 
tax regulations, tax rates and access to financing as the main problems.

On the other side, most Croatian entrepreneurs have agreed that the greatest obstacles to doing business are low efficiency of public administration, destimulating tax rates, policy instability, tax regulations and corruption. Slovenian entrepreneurs mostly criticise destimulating tax rates, low efficiency of public administration and restrictive labour regulations.

In all three countries observed entrepreneurs point out low efficiency of public administration as the key problem. With the aim of improving the business environment, building a fast and efficient public administration with emphasis on e-management at all levels should be in the focus of competent institutions in the countries observed. The countries observed should focus on elimination of regulatory and administrative obstacles, burden on doing business and development of electronic procedures for starting-up and doing businesses. In addition to efficiency of public administration, political stability and clear and predictable policy management and decisionbringing processes on the institutional level are of key importance for entrepreneurs in $\mathrm{B} \& \mathrm{H}$. The analysis clearly shows that it is difficult to expect $\mathrm{B} \& \mathrm{H}$ to become attractive to entrepreneurs and investors without resolution of political issues and achieving stability.

\subsection{Doing Business Report}

The Doing Business Report deals with the ease or difficulty of starting and running businesses by entrepreneurs. Research carried out in 190 countries analyses changes in regulations affecting 10 business areas of small and medium-sized enterprises, relating to: business start-up, construction permit obtainment, electrical energy supply, property registration, credit obtainment, investor protection, tax payment, cross-border trading, trade dispute settlement and insolvency resolution. This year's Doing Business Report also contains revised data for 2016, considering that there have been changes in methodology during the last year. 
Table 4: Results of the 2017 Doing Business Report with regard to Bosnia and Herzegovina and their comparison with results of Central and Eastern European Countries

\begin{tabular}{|c|c|c|c|c|c|c|c|c|c|c|c|}
\hline Estonia & 12 & 14 & 9 & 38 & 6 & 32 & 53 & 21 & 17 & 11 & 42 \\
\hline Latvia & 14 & 22 & 23 & 42 & 23 & 7 & 42 & 15 & 25 & 23 & 44 \\
\hline Lithuania & 21 & 29 & 16 & 55 & 2 & 32 & 51 & 27 & 19 & 6 & 66 \\
\hline \begin{tabular}{|l|} 
Slovenia \\
\end{tabular} & 30 & 49 & 80 & 16 & 34 & 133 & 9 & 24 & 1 & 119 & 12 \\
\hline Slovakia & 33 & 68 & 103 & 53 & 7 & 44 & 87 & 56 & 1 & 82 & 35 \\
\hline Romania & 36 & 62 & 95 & 134 & 57 & 7 & 53 & 50 & 1 & 26 & 49 \\
\hline Bulgaria & 39 & 82 & 48 & 104 & 60 & 32 & 13 & 83 & 21 & 49 & 48 \\
\hline Hungary & 41 & 75 & 69 & 121 & 28 & 20 & 81 & 77 & 1 & 8 & 63 \\
\hline Croatia & 43 & 95 & 128 & 68 & 62 & 75 & 27 & 49 & 1 & 7 & 54 \\
\hline
\end{tabular}

Source: 2017 Doing Business Report ${ }^{28}$

New Zealand is at the top of the ranking due to an exceptionally favourable business environment (a single document is required for starting a business, and the procedure lasts only several hours. In comparison, in Bosnia and Herzegovina 12 documents are required, while the procedure lasts 65 days). Singapore, Denmark, Hong Kong, South Korea and Norway follow. Of Central and Eastern European Countries, Estonia, Czech Republic, Lithuania, Poland and Latvia stand out, whereas Bosnia and Herzegovina is at the bottom of the ranking, 34 positions below Serbia. Libya(188), Eritrea (189) and Somalia (190) are at the bottom of the ranking. In this year's report it is stated that 137 world economies have implemented a total of 238 regulatory reforms during the last year, that is, $20 \%$ more in relation to the preceding year. The area of Europe and Central Asia which B\&H belongs to is the area with the largest percentage of countries which have implemented at least one proposed reform this year also.

Of the surrounding countries, Serbia, which belongs to the group of ten countries which have made the greatest progress in relation to last year's position, adopted the largest number of reforms, recorded in

${ }^{28}$ http://www.doingbusiness.org/ /media/WBG/DoingBusiness/Documents/AnnualReports/English/DB17-Report.pdf 
three areas: business start-up, construction permit obtainment and property registration.

As the tenth country in the world with regard to ease of doing business, Macedonia continues with its positive trend this year also, and is best positioned in the area of ease of doing business, wherein it is fourth in the world, that is, starting a business requires two days. Furthermore, significant progress has been made with regard to access to credits, protecting minority investors and insolvency resolution.

As regards Montenegro, a three-position drop has been recorded, that is, it is ranked 51st in relation to the 48th position in last year's report. Progress has been made in only one area (tax payment), which has been eased with the introduction of an electronic system for submission and payment of value added tax. Montenegro is seventh in the world according to the credit obtainment indicator, whereas the lowest position is recorded in the area of electrical energy supply.

In this year's 2017 Doing Business Report, Bosnia and Herzegovina is ranked 81 st out of 190 countries included in the research. Although with this score it has progressed by two positions, it is still lowest ranked in relation to all surrounding countries.

As regards individual evaluations (shown in Table 5), positive movements in two categories have been recorded. Doing business has been eased through reduction of required minimum capital for limited liability companies and increased efficiency of the public notary system. Furthermore, progress has been made in the „Tax payment“ category due to abolishment of charges for tourist communities. In all other areas B\&H records lower ranking in relation to last year's results, for example in the „Electrical energy supply“ category, seeing that 8 documents are required for installation of an electrical energy connection, with the entire procedure lasting 125 days (in Korea, which is ranked first, the procedure lasts 18 days, with 3 documents required). In the area of insovency resolution and credit obtainment procedure, $\mathrm{B} \& \mathrm{H}$ is ranked $41 \mathrm{st}$, that is, 44th. An extremely low position is occupied in the area of construction permit obtainment, which requires 15 documents, with the entire procedure lasting 179 days (in comparison, the highest ranked country in this category is Singapore, where the procedure lasts 48 days, with 9 documents required). 
Table 5. Results of the Doing Business Report for Bosnia and Herzegovina and comparison with last year's results

\begin{tabular}{|l|r|r|r|}
\hline Area & DB 2016 & DB 2017 & \multicolumn{1}{|c|}{ Change } \\
\hline Business start-up & 175 & 174 & -2 \\
\hline Construction permit obtainment & 168 & 170 & -3 \\
\hline Electrical energy supply & 120 & 123 & -2 \\
\hline Property registration & 97 & 99 & -2 \\
\hline Credit obtainment & 42 & 44 & -3 \\
\hline Protection of minority investors & 78 & 81 & 18 \\
\hline Tax payment & 151 & 133 & -1 \\
\hline Cross-border trading & 36 & 36 & No changes \\
\hline Contract fulfilment & 63 & 64 & -1 \\
\hline Insolvency resolution & 40 & 41 & \\
\hline
\end{tabular}

Source: World Bank, Doing Business Report

Finally, the presented analyses show that the main reasons for the drop in competitiveness of $\mathrm{B} \& \mathrm{H}$ are insecure and unpredictable government policies, inefficient regulative and legal framework, low crisis resilience, numerous market and administrative obstacles, unstable tax system, extremely high unemployment level, underdeveloped entrepreneurship, low level of investment into research and development and knowledge transfer. B\&H must focus on implementation of structural reforms with the aim of mobilising investment and opening new workplaces in order for the economy to recover, and that includes fiscal discipline, export-oriented production and strengthening entrepreneurship.

\section{A COMPARATIVE ANALYSIS OF B\&H AND CENTRAL AND EASTERN EUROPEAN COUNTRIES MACROECONOMIC INDICATORS}

$\mathrm{B} \& \mathrm{H}$ is characterized by weak movements of macroeconomic indicators, especially compared to Central and Eastern European Countries. As stated in the 2016 Progress Report ${ }^{29}$, labour market conditions in $\mathrm{B} \& \mathrm{H}$ have remained unchanged, while public finance, business environment and public sector management have deteriorated. Low level of investment in the private sector, which

${ }^{29}$ European Commission: 2016 Report on Bosnia and Herzegovina. More information available at:

http://www.dei.gov.ba/dei/media_servis/vijesti/default.aspx?id=17696\&langTag=hr$\underline{\mathrm{HR}}$ 
should generate economic growth, production, exports and creation of new workplaces, represents the main problem. Particular macroeconomic indicators, from economic growth and balance of payments to labour market indicators, point precisely at those weaknesses.

In $2015 \mathrm{~B} \& \mathrm{H}$ recorded a 2,8 percent growth of real gross domestic product (real GDP). In relation to observed Central European countries (Czech Republic, Slovakia, Poland, Hungary, Slovenia and Croatia), B\&H grew slower than the observed countries by average, but recorded a higher economic growth rate than Slovenia and Croatia. According to IMF data ${ }^{30}$, since the beginning of the crisis in 2008 to $2015 \mathrm{~B} \& \mathrm{H}$ grew by 6,3 percent, occupying the 144th position out of 189 countries, that is, 45 countries grew slower or recorded an economic downfall in that period. Only eight countries were lower ranked.

Figure 2: Real GDP growth rates (\%)

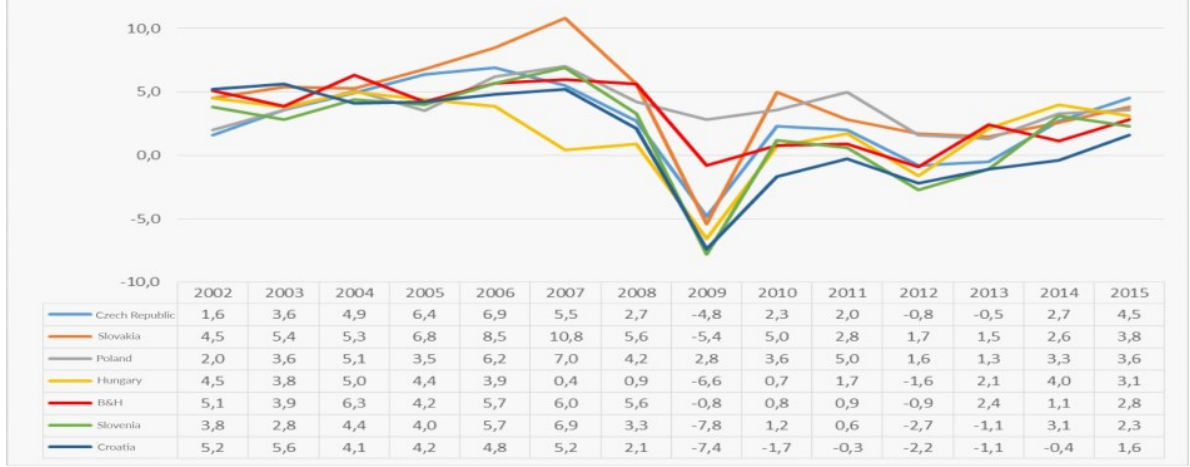

Source: Eurostat, IMF

With regard to GDP per capita in PPS in relation to EU28, B\&H has been converging during the last ten years but with the characteristic of very slow growth. Thereby in 2005 B\&H's GDP per capita in PPS in relation to EU28 amounted to $24 \%$, whereas it amounted to $29 \%$ in

\footnotetext{
${ }^{30}$ https://www.imf.org/external/pubs/ft/weo/2016/01/weodata/download.aspx, World Outlook Database April 2016.
} 
the last four years, making it lowest ranked in relation to observed countries, which have recorded levels amounting to $58 \%$ and higher.

Figure 3: GDP per capita in PPS (\% of EU average)

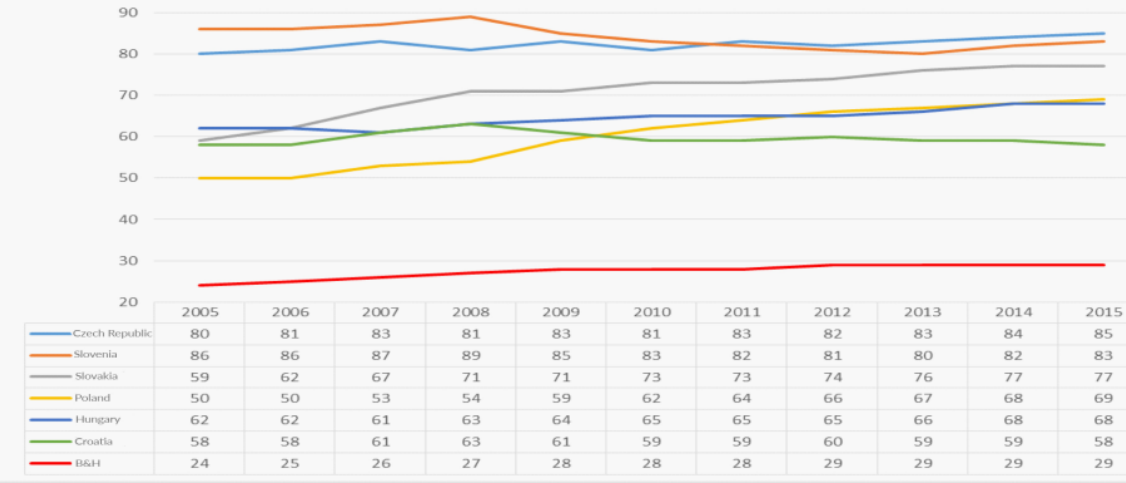

Source: Eurostat

$\mathrm{B} \& \mathrm{H}$ records the largest current account deficit in relation to observed Central European countries. Thereby in 2015 the current account deficit amounted to $6,8 \%$ of GDP, which represents a one-point drop in relation to the preceding year. The other observed countries recorded a significantly lower current account deficit, or even a surplus, as that is the case with Slovenia, Croatia and Hungary.

Figure 4: Current account balance ( $\%$ of GDP)

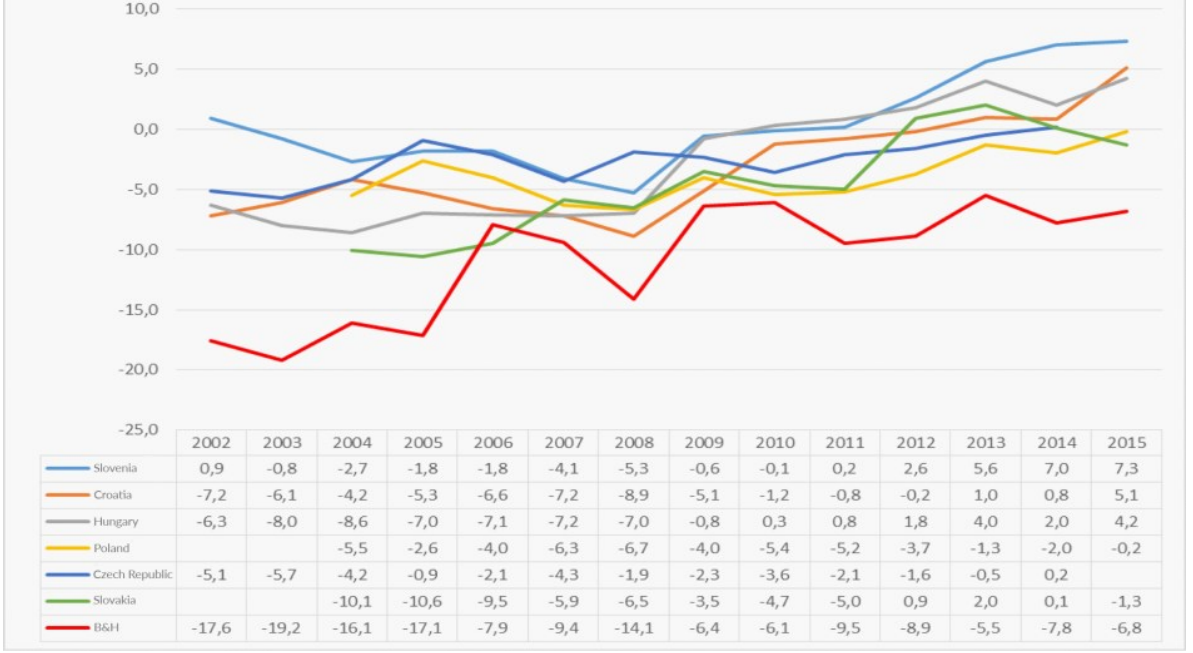

Source: Eurostat, IMF 
Bosnia and Herzegovina also records the largest goods trade deficit, that is, the difference between imports and exports of goods. In 2015 Bosnia and Herzegovina recorded a deficit amounting to $26,1 \%$ of GDP, whereas the other observed countries recorded a surplus, with the exception of Croatia, whose deficit amounted to $15,1 \%$ of GDP.

Figure 5: Goods trade surplus/deficit (\% of GDP)

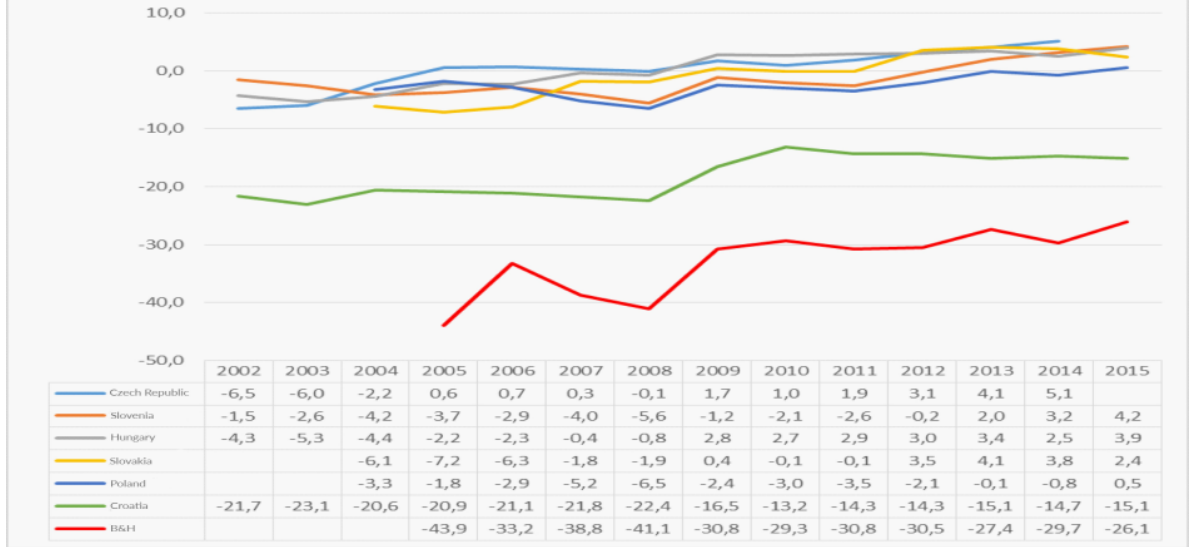

Source: Eurostat, IMF

According to labour market indicators Bosnia and Herzegovina is lowest ranked in relation to observed Central European countries. In 2015 Bosnia and Herzegovina recorded an unemployment rate of $27,7 \%$, which has been stagnating for the last three years. In other observed countries unemployment rates are decreasing, whereby four countries have an unemployment rate under $10 \%$. 
Figure 6: Unemployment rate (\%)

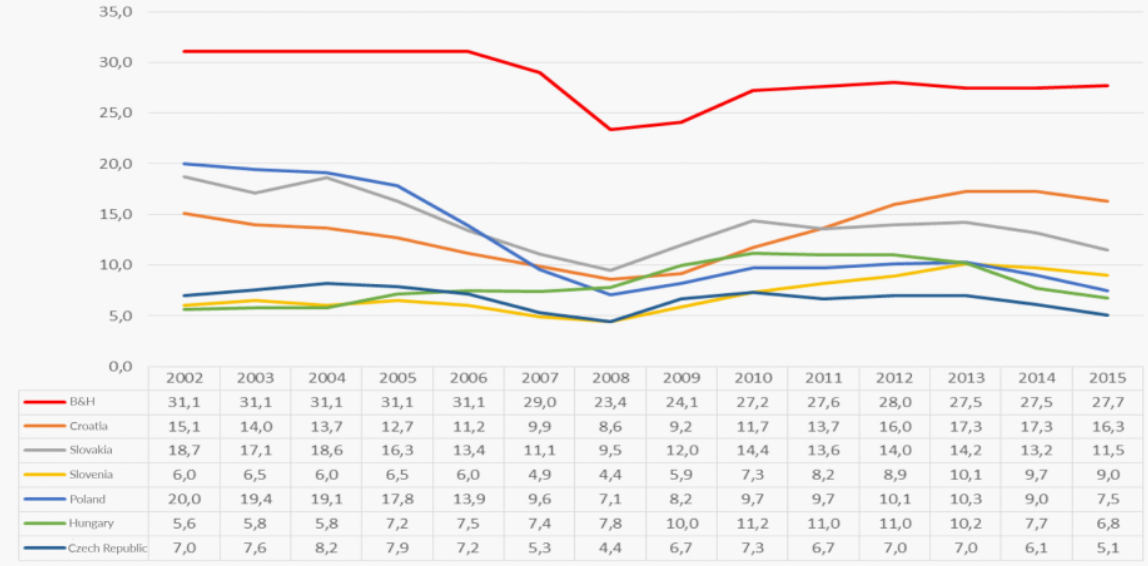

Source: Eurostat, IMF

On the other hand, Bosnia and Herzegovina recorded an employment rate of only $31,9 \%$ in 2015 , whereas the other observed countries recorded employment rates above $60 \%$.

Figure 7: Employment rate (\%)

Source: Eurostat, Agency for Statistics of B\&H

$\mathrm{B} \& \mathrm{H}$ is at the very bottom compared to Central European countries, and is below $30 \%$ of European Union average in view of level of development. That points to the necessity of implementation of structural reforms in order to mobilize the private sector, which must be the main generator of growth and increase in employment, and 
which will gradually bring $\mathrm{B} \& \mathrm{H}$ closer to the EU average. Negotiations with the European Union will significantly contribute to implementation of changes required in order to strengthen $\mathrm{B} \& \mathrm{H}$ politically, legally and economically.

\section{CONCLUSION}

$\mathrm{B} \& \mathrm{H}$ is facing the second phase on the way to the EU, which is the attainment of a "candidate country“ status. The common objective of the European Commission, B\&H and EU Member States is that the process of preparation of answers to questions in the Questionnaire, but also analysis of the answers by the European Commmission be fast and efficient, and that, with amendment of the electoral law and quality functioning of the coordination mechanism, B\&H attains the status of a candidate country and swiftly passes into the third phase, which presents the formal negotiations. This is important for modernisation and democratization of the country, strengthening the legal and political system in which high standards of protection of human and minority rights and equal participation of all three constituent nations in institutions and decision-making processes in $\mathrm{B} \& \mathrm{H}$. B\&H's way to Europe is the key for the existence of constituent nations, especially for attaining equality of the Croatian nation and further development and stability of B\&H.

According to economic strength, B\&H's GDP per capita in PPS amounts to $29 \%$ compared to EU28 average, which is far below the least developed Member States, Bulgaria, Croatia and Romania. In addition to political and legal security, implementation of reforms and sizable investments into transport, environmental and public entrepreneurial and social infrastructure, modernisation of technologies, innovation and research and development are required. Investments in $\mathrm{B} \& \mathrm{H}$ are of great importance, which is why the European Commission should realize fast and quality implementation of IPA II programme in all areas/components in cooperation with $\mathrm{B} \& \mathrm{H}$ institutions. It is also important to focus other financial instruments developed at EU level, such as the European Fund for Strategic Investments (EFSI), on the B\&H market in order to accelerate the process of encouraging economic growth and creation of workplaces in B\&H. Structural reforms relate to: increasing the 
efficiency of public administration; policy stability; easier access to financing; efficient labour legislation, workforce education including improvement in work ethics; attracting and retaining talented individuals; reduction of corruption, crime and fraud; improvement of infrastructure, especially technological infrastructure, improvement of innovation capacity; a more efficient legal framework, especially with regard to foreign investments; reduction of wastefulness of government spending; cluster development; fiscal discipline; a simple, stable and just tax system; reduction of tax burden on entrepreneurship; availability of venture capital; reduction of obstacles to foreign direct investment and technology transfer; improvement in access to credits, especially with regard to startups and small and medium-sized enterprises (SME); improvement of education system quality and reduction of the gap between the education system and the labour market; increase and reform of public investment in research and development.

\section{LITERATURE}

1. BiH Integration Initiative: steps to membership in the European

Union. More at: http://eu-monitoring.ba/koraci-ka-clanstvuevropskoj-uniji/

2. Delegation of the European Union (2017.), "Bosnia and Herzegovina joins COSME, the EU programme for small and medium-sized enterprises", available at: http://europa.ba/?p=43027, reviewed on 8 September 2017.

3. Directorate for European Integration (2013.), "Introduction of a new Instrument for Pre-Acesssion Assistance IPA II (2014-2020)", available at:

http://www.dei.gov.ba/dei/direkcija/sektor_koordinacija/ipa_2/defau 1t.aspx?id=11610\&langTag=hr-HR,reviewed on 8 September 2017.

4. Directorate for European Integration: Chronology of the relationship between $\mathrm{BiH}$ and the EU. More at:

http://www.dei.gov.ba/dei/bih_eu/default.aspx?id=9808\&lang $\underline{\text { Tag }=\text { hr-HR }}$

5. Directorate for European Integration: The Stabilisation and Association Agreement between the European Communities and their Member States on the one part and Bosnia and Herzegovina on the other part. More at: http://www.dei.gov.ba/bih i eu/ssp/doc/default.aspx?id=743\&langTag=bs-BA 
6. Doing Business Report (2017.), Equal Opportunity for All, More at: http://www.doingbusiness.org/ /media/WBG/DoingBusiness/Docu ments/Annual-Reports/English/DB17-Report.pdf

7. EU info centar (2016.), "IPA 2017 programming process in Bosnia and Herzegovina is ongoing", available at: http://euinfo.ba/procesprogramiranja-ipa-2017-u-bih-u-toku/, reviewed on 8 September 2017.

8. European Commission (2017), "Bosnia and Herzegovina - financial assistance under IPA II", available at

https://ec.europa.eu/neighbourhoodenlargement/instruments/funding-by-country/bosniaherzegovina en, reviewed on 8 September 2017.

9. European Commission: Report on Bosnia and Herzegovina for 2016. More at:

http://www.dei.gov.ba/dei/media_servis/vijesti/default.aspx?id=176 96\&langTag=hr-HR

10. European Court of Human Rights (ECHR): court case; Sejdić and Finci v. Bosnia and Herzegovina (Application No. 27996/06 and 34836/06). More at:

http://www.mhrr.gov.ba/ured zastupnika/novosti/default.aspx?id=1 008\&langTag=bs-BA

11. European Neighbourhood Policy And Enlargement Negotiations: Screening of the acquis. More at: https://ec.europa.eu/neighbourhood-enlargement/policy/glossary/ terms/screening_en

12. European Neighbourhood Policy and Enlargement Negotiations: Steps towards joining. More at: https://ec.europa.eu/neighbourhoodenlargement/policy/steps-towards-joining en

13. European Parliament (2013.), A short guide to the European Union. Luxembourg: The Publications Office of the European Union

14. Ministry of Foreign Affairs of the Republic of Croatia: Summarized overview of the results of the accession negotiations by chapters.

More at: http://www.mvep.hr/cust ompages/static/hrv/files/pregovori/120112-sazeti.pdf

15. Negotiations on Croatia's accession to the European Union (2006.) Zagreb: Ministry of Foreign Affairs of the Republic of Croatia. More at: http://www.mvep.hr/files/file/publikacije/MEI hr_web_pass.pdf

16. Strohmeier, R.W., Habets, I. (2013.) EU Policies: an Overview. Brussels: Centre for European Studies

17. The Treaty on European Union, Official Journal of the European Union 326/13. More available at: http://eur-lex.europa.eu/legal- 
content/EN/TXT/PDF/?uri=CELEX:

12012M/TXT\&from=en

18. United Nations Development Programme (2015.), Work for Human Development. More at:

http://hdr.undp.org/sites/default/files/2015 human development_rep ort.pdf

19. World Economic Forum (2016.), Global Competitiveness Report 2016-2017, More at: http://www3.weforum.org/docs/GCR20162017/05FullReport/TheGlobalCompetitivenessReport20162017 FINAL.pdf

20. World Economic Forum (2016.), Global Information Technology Report 2016 - Innovating in the Digital Economy. More at: http://www3.weforum.org/ docs/GITR2016/WEF_GITR_Full_Report.pdf 